\title{
A FOGYASZTÓK ÉLETÚTJA A SZLOGENEK VILÁGÁBAN
}

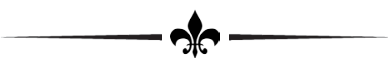

\author{
THE LIFECYCLE OF CONSUMERS IN THE WORLD OF SLOGANS
}

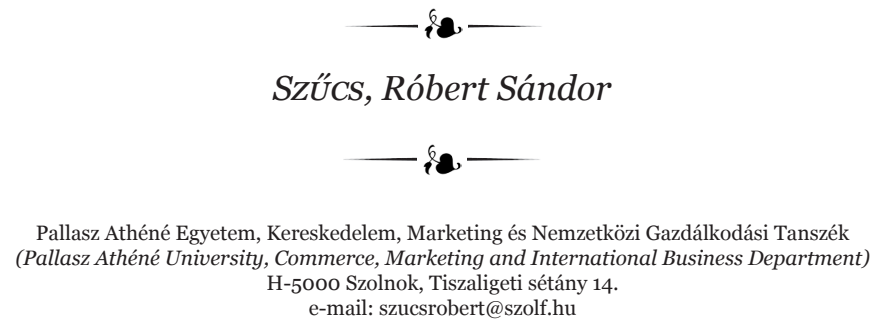

gi

Nowadays children face lots of slogans every single day. A good slogan generates feelings. Of course these feelings, brand names and slogans can be placed in mind of children by marketing experts. The remembering rate of slogans is shockingly high, higher than is the case of their parents. We can state that well-placed slogans play a very important role in influencing children. All of these contribute to the development of brand loyalty, which - if it develops during childhood - can last an entire lifetime. My primary research (sample size is 1222 children and 610 youth and adult) justifies this statement. My research shows the remembering rate of slogans and brand names in case of different foods with high level of fat-, sugar- and/or salt content in the segment of children, youth and adults.

KuLCSSZAVAK: gyermekek, szlogen, márka, marketing, reklámozás

JEL-KóDoK (JEL CODES): M31, M37

\section{BEVEZETÉS - INTRODUCTION}

A XXI. században a reklámok elsőszámú célközönségévé a gyermekek váltak. Leginkább ez a szegmentum lett az, melyet a vállalatok tömege klasszikus reklámok (és új, kreatív eszközök) segítségével próbál meggyőzni, kihasználva tapasztalatlanságukat, korántsem kiforrott preferenciarendszerüket. A hatást fokozza, hogy napjainkban a gyermekek gyakran szüleik nélkül nézik a televíziós müsorokat, nem ritkán a szobájukban található saját készüléken, kontroll nélkül. A gyermek- és fiatalkorúak célcsoportja különösen fogékony mindenféle újdonságra, fóleg ha mindezt új, színes, hangos eszközökkel tálaljuk számukra, lehetőség szerint egyszerü módon. Természetesen a vál-
KEYWORDS: children, slogan, brand, marketing, advertisement lalatok is tisztában vannak ezzel, amely jelenséget kihasználva tömegesen céloznak meg egy önálló jövedelemmel nem rendelkező, de befolyásolható korosztályt.

\section{A GYERMEKEK BEFOLYÁSOLÁSA - INFLUENCING CHILDREN}

ÚJVÁRI (2007) az alábbi néhány sorban kiválóan összefoglalta a szlogenek lényegét: „A szlogen olyan szókapcsolat, amely egy reklámban használva a vállalkozás, a márka, a termék, a politikai párt vagy a promóció lényegére, fó üzenetére koncentrálva kíván erős visszaidézési hatást elérni. A jó szlogen megragad az em- 
berek emlékezetében. Ezt kétféleképpen tudja elérni: egyrészt rengeteg ismétléssel a különféle reklámokban legyen az leírva vagy kimondva vagy mindkettő; másrészt egyedi, a népszerüsített cégre, termékre utaló szókapcsolattal. A szlogenek java része kevés értékkel bír. Nem egyediek, könnyedén felcserélhetők bármely más cég, márka, termék vagy akár politikai párt szlogenjével. Értékük sokszor csak akkor lesz, ha hosszú éveken keresztül ismételgetik a fogyasztók számára.” Egy másik érdekes definíció szerint a szlogen pszichológiailag megalapozott és megfogalmazott módja annak, hogy a fogyasztók milyen vágyak által vezérelten vásárolják meg és próbálják ki a terméket a lehetô leggyorsabb módon (DIMO és COLENCIUC, 2010).

A szlogen gyakori ismétlése teremti meg annak igazi befolyásoló erejét. Különösen egy olyan szegmentum esetében rendelkeznek kiemelt befolyásoló erővel, melynek képviselői pozitív attitűdöt mutatnak fel a reklámokkal szemben, kedvelik azokat, szórakoztatónak ítélik őket. A hatást erősíti a reklámok nézésével eltöltött magas óraszám (például a televízióban), illetve az, ha a szegmentum tagjai még nem képesek önálló véleményformálásra, nincs kialakult preferenciarendszere. A csoport a leírtak alapján könnyen beazonosítható, a gyermekek korcsoportjáról beszélünk. A szlogen sikerességének kulcsa két tényezőben gyökerezik:

- a televízió nézésre fordított idő alakulásában és

- a gyermekek befolyásolhatóságának mértékében.

A televízió nézésre fordított idő alakulását az AGB Nielsen Médiakutató adatai alapján szemléltetem. Kutatásuk szerint 2013-ban a teljes népesség átlagosan 4 óra 46 percet, azaz 286 percet töltött a televízió előtt naponta. A 18 év alattiak tévénézéssel töltött ideje 3 óra 11 percről 3 óra 22 percre nőtt, a 18-49 éves korcsoporté pedig 4 óra 1 percre emelkedett 2012rôl 2013-ra. Az 50 év felettiek átlagosan 6 óra 10 percet töltöttek a televízió előtt, 5 perceel kevesebbet, mint 2012-ben. 2013-ban a 4 év feletti teljes népességet alapul véve naponta átlagosan 7,1 millió ember kapcsolta be legalább egy percre a televízióját, és közülük 6,7 millió látott legalább egy hirdetést. Az egy főre jutó átlagos napi reklámnézési idő 23 percet tett ki, ez a teljes tévénézési idő 8 százaléka. Egy néző naponta átlagosan 78 darab reklámot látott (AGB NIELSEN, 2014). Megdöbbentően magas számok.

A gyermekek befolyásolhatóságának mértékét több szerző is vizsgálta. PIAGET és INHELDER (1966; 1999) és COFFEY és szerzőtársai (2006) az életkort vette alapul a meghatározásuknál. Kutatásukban a 3-tól 7 éves életkorig tartó szakaszt múveleti szakaszként említik. Ez az a korszak, ahol a gyermek beszélni kezd. A gyermek 6 éves korára 8 ooo-14 000 szó közötti szókinccsel rendelkezik. A három leggyakrabban elhangzó szó: „Én... akarom ... azt!”. Intelligenciájuk és kognitív képességeik gyors fejlődésen megy keresztül, de még koránt sem kiforrott. A szakaszt jellemzi az egydimenziós gondolkodás, vagyis a pontos átlátási képességek és a megértés képességének hiánya. Ennek következtében a gyermekeket a hiszékenység jellemzi leginkább ebben a szakaszban, a számukra mondott információt (pl. reklámüzenetben) tényként kezelik. Könnyü belátni, hogy ebben a szakaszban a könnyen és gyorsan megérthető, egyszerü szlogenek nagy hatást képesek elérni a gyermekeknél. A következő szakaszt a konkrét műveleti szakasz (7-11 éves korig). Ebben a szakaszban a gyermekeket a gondolkodás jellemzi. A márkák egyértelműek a gyermekek számára, az alapvető márkapreferenciák kialakultak. Könnyen kihasználható, hogy a gyermek számára a márka és termék azonos kategóriát jelent. Nem érzékelik a különbséget, ami különösen sebezhetővé teszi őket. A gyermek sok esetben nem termékhez, hanem a márkához ragaszkodik. A gyermekek döntését erőteljesen befolyásolják a színek, a karakterek, mesefigurák, logók. Könnyedén befolyásolhatók az úgynevezett brand licencing eszközével is, vagyis a terméken megjelenő, illetve termékhez járó mesefigurákkal. A lényeg újra a könnyű megjegyezhetőség, amely tulajdonságok a szlogenekre is jellemző. Mindennek következménye, hogy akár a 7. életévtől korábban is, akár 5 éves kortól a gyermekek már kérnek/követelnek különböző márkanevű termékeket.

A két tényező hatása a következőkben öszszegezhető. A gyermek ül a televízió előtt és a 
műsort megszakító reklámblokkok által olyan reklámüzeneteket is befogad, amely nagy valószínűséggel a vele élő felnőttek figyelmét elkerüli. Már csak ezért sem mehetünk el a reklámok mellett szó nélkül, mivel a modern fogyasztói társadalomban mindenki ki van téve a szinte állandó reklámhatásnak, így a gyermekek is (SIMAY, 2009). Tény az is, hogy a gyermekek 3 éves kor fölött felismerik a márkajeleket, de a márkahűség kialakításának kezdete már 2 éves kortól elindulhat (FISCHER et al., 1991; McNEAL, 1992). VEKERDY (2000) szerint az 5 éves korig kialakított márkahüség tartós, és akár egy egész életen át elkísér. A serdülők márkafüggése rapszodikus és sokszor hisztérikus. Az Amerikai Pszichológiai Társaság (APA) külön bizottságot hozott létre, hogy kivizsgálják a kereskedelmi hirdetések gyermekekre gyakorolt hatásait. Azt találták, hogy 4-5 éves kor alatt a gyermekek nem tudnak megfelelő különbséget tenni a müsorfolyamban jelentkező hirdetések és a többi müsor között. Nem ismerik fel, hogy számukra valamit értékesíteni szeretnének (COMSTOCK, 1991). Mindezt fokozza, hogy a gyermekekre irányított marketing célja, hogy a gyermekek a lehető legkorábban azonosítsák és differenciálni tudják a termékeket márkanév/jel alapján. Zárójelesen megjegyezhető, hogy ennek egyszerű és kiváló eszköze a szlogen, mely segíti a terméket/márkát a pozícionálásban. Tény, hogy egy 2 éves gyermeknek már vannak elképzelései a márkákat illetően, a 2-6 évesek már egyértelmüen felismerik és azonosítják a legismertebb márkákat név, csomagolás, logó alapján (DERSHEID, 1996; MACKLIN, 1996). Az 5-8 évesek már számos márkanevet fel tudnak sorolni a gyermekeknek szánt termékek közül (MCNEAL, 1992). LÁTOS (2005) szerint az ötéves gyermekek már 20-30 terméket felismernek a reklám dallama és logó nyomán, ami kiegészül a kívánt termék megszerzésére irányuló nyaggatási faktorral (RUST, 1993). További felmérés igazolta, hogy a 3 éves gyermekek 20 százaléka már ragaszkodik bizonyos márkákhoz és befolyásolja a szülőt annak megvásárlásában (LÁTOS, 2005). LINN (2008) álláspontjára felhívva a figyelmet, mindezt úgy teszik, hogy a fiatalkorúaknak szóló reklámok nagy része energiában gazdag, ugyanakkor alacsony tápértékü élelmiszer. Az évi 40000 darab megtekintett reklámfilmből egy átlagos gyermek 10 ooo darab élelmiszerreklámot lát, aminek 90\%-a cukrozott üdítőt, édességeket, gabonapelyhet és gyorséttermi ételt hirdet. Brownell megfogalmazásával élve a gyermekek befolyásolásának mértéke „nem fair” (SPURLOCK, 2004).

Nem kétséges a fenti közvetlen és közvetett adatok tükrében, hogy egy jól megalkotott szlogen milyen mértékben képes befészkelni magát a gyermekek fejébe. A szakirodalom hiányosságának ítélem, hogy konkrét számszaki adatokat nem vagy csak nagyon elvétve találunk a szlogenek hatékonysága vagy viszszaidézése kapcsán. BARTA és SZƯCS (2015) írásában rávilágít a szlogenek visszaidézési arányaira. Kutatásuk során élelmiszeripari márkanevekhez kapcsolódó szlogeneket említettek a gyermekeknek, majd a fókuszcsoport módszerével a felidézési képességüket „tesztelték" (Kösse össze a gyermek a megfelelő szlogent a megfelelő márkanévvel). A feladat során adott volt 10 darab szlogen és 10 darab márkanév a gyermekek számára. A feladat a szlogenek és márkanevek helyes összepárosítása volt, vagyis nem a spontán visszaidézési képességeket mérték. A fókuszcsoportos kutatásban résztvevő 5x3 (összesen 15 fó) gyermekből 12 gyermek az összes márka szlogenjét hiba nélkül helyesen beazonosította. A sikeres válaszok aránya megdöbbentően magas, így szükségesnek ítéltem a kutatás nagymintás vizsgálatának megvalósítását úgy, hogy a kvalitatív kutatási módszert kissé kvantitatívra alakítsam át, nem elveszítve a kvalitatív jelleget.

\section{ANYAg ÉS MÓDSZER -}

\section{MATERIAL AND METHOD}

A szekunder információkra alapozva primer kutatást végeztem. A kutatás célja megvizsgálni a gyermekkorúak szlogenekhez/márkákhoz/ reklámokhoz való viszonyulását különös tekintettel arra, hogy a gyermekkorúak mennyire képesek visszaidézni a hallott szlogen alapján a termék pontos márkanevét. Számos szerzó rámutat arra a tényre, hogy a gyermek- és fiatalkorúak már egészen kis koruktól kezdve ragaszkodnak márkákhoz, márkanevekhez, de kevesen vizsgálják a márkanévnek a hallott 
szlogen alapján történő spontán visszaidézési képességét; vagyis, ha a gyermekkorú hall egy szlogent vajon képes-e visszaidézni azt, hogy mely márka szlogenjét hallotta. Kutatásom jelenlegi fázisában arra vagyok kíváncsi, hogy az élelmiszergyártók marketingtevékenysége mennyire hatékony a gyermekek szegmensében, a vállalati marketingaktivitás (kiemelten a szlogen) mennyire képes a gyermekek tudatába befészkelni magát. A kutatás lényege, hogy a kérdezőbiztos a megkérdezett gyermekkorú személynek élelmiszeripari termékekhez kapcsolódó szlogeneket említ (szóbeli megkérdezés módszere), majd kéri a gyermeket, hogy a hallott szlogen alapján - segítség nélkül mondja meg azt, hogy mely márkához kapcsolódik a hallott szlogen (spontán felidézés).

A kutatás során az alábbi szlogenek kerültek megemlítésre, zárójelben jelzem a helyes megoldásokat:

- „Igyál még egy pohárral és fogd rá a nyuszira” (Nesquik),

- „Pöttyös az igazi” (Pöttyös Túró Rudi),

- „Megáll az eszed, ha eszed” (Cheetos),

- „Ha kell egy kis energia” (Sport szelet),

- „Mindig bejön a fóétkezések között” (Kinder tejszelet),

- „Merj gyengéd lenni” (Milka),

- „Az élet Coke oldalán” (Coca-Cola),

- „Délig tartó lendület” (Belvita JóReggelt),

- „Ronda és finom” (Chokito),

- „Az élet nálunk mindinkább tejes” (Mizo),

- „Gyümölcsös rostos ital, egészséges, tele vitaminnal" (Kubu),

- „Minél inkább csoki, annál inkább ." (Boci),

• „Kinder .................. a hútőből” (Pingui).

A szlogenek kiválasztásánál egy korábbi kutatásra támaszkodtam, alapul véve BARTA és SZƯCS (2015) kutatását. A kiválasztásnál lényegében a véletlenszerüség dominált, illetve - mindenféle mérés nélkül mondva - ezek a szlogenek jelentősnek nevezhető médiaaktivitást valósítottak meg. A kutatásban mindösszesen 1222 fő gyermek vett részt, hat és tizenegy éves életkor között. A szóbeli megkérdezés szülői jóváhagyás mellett valósult meg. Korukból adódóan (írás és olvasási készségek hiánya) a szóbeli megkérdezés bizonyult a leginkább megvalósítható megoldásnak a korukhoz igazodó egyszerű metódussal. A kutatásban 618 lány és 604 fiú vett részt, mely 50,6\%-os és 49,4\%-os nem szerinti megoszlást tükröz. A minta életkorát tekintve egyenletes eloszlású, minden életévhez a megkérdezettek 10-13\%-a tartozik. Egyetlen életkorú csoport sem alul-, illetve felülreprezentált a mintában. A minta átlagos életkora is alátámasztja ezen kijelentést (átlagos életkor a mintában 9,96 év). A gyermek 60,1\%-a városban, 22,8\%-a faluban, 15,1\%-a megyeszékhelyen, 2,0\%-a a fővárosban lakik. A megkérdezett gyermek lakóhelye az elemzések során (mint az már sokszor igazolásra került a korábbi kutatásaim során is: SZỨCS, 2011) lényegtelen tényezőnek nevezhető. A megkérdezettek az ország 14 megyéjéből kerültek ki, melyek közül a leginkább domináns volt Jász-Nagykun-Szolnok megye, Pest megye, Bács-Kiskun megye, Békés megye és Csongrád megye. Az adatfelvételre 2015. október 31. és 2015. december 2. között került sor.

A kutatás késóbbi fázisában a további kérdések megválaszolása érdekében 610 fó fiatal- és felnőtt korú személyt kérdeztünk meg a korábbiakkal azonos kérdőív és a fentebb leírt módszertan segítségével. A lekérdezés 2016. április 3. és 2016. május 18. között történt. A kutatásban a megkérdezettek 44,8\%-a 20 éves életkor alatti (de 14 évestől idősebb), míg 55,2\%-a 20-30 éves életkor közötti volt. A megkérdezettek 49,3\%-a férfi, míg 50,7\%-a nő volt

\section{EredménYek - RESUlts}

A kutatás során megállapítható volt, hogy a legkisebb gyermekek a reklámokat meglehetősen szórakoztatónak találják, azokkal szemben igen pozitív attitűdöt mutatnak fel. Kutatásom számszerűen is igazolja a szekunder irodalom állításait. Ez a pozitív attitűd azonban az életkor előrehaladtával folyamatosan veszít intenzitásából. A reklámok szórakoztató képességének vizsgálata érdekében kértem, hogy a kérdezőbiztosok érdeklődjenek a gyermekektől arra vonatkozóan, hogy mennyire szeretik, mennyire találják szórakoztatónak a kereskedelmi reklámokat. A gyermekek által elmondottakat a kérdezőbiztosok 5 fokozatú Likert-skála segítségével számszerüsítették, 
ahol az 1-es érték jelentette a teljes elutasítást a reklámok szórakoztató képességét illetően, illetve az 5-ös érték jelentette a maximális szórakoztató képességet, a leginkább pozitív attitüdöt. A nagy számok törvénye, az 1222 fó megkérdezett gyermek száma pedig biztosítja a szubjektivitás kizárását a kérdezőbiztosi oldalról, illetve az általánosan megfogalmazható trendek leírását. A reklámokkal szembeni attitűdök pozitív mivoltának megítélésében a már említett 5 fokozatú Likert-skála 4 és 5 értékei nyújtanak segítséget; ezek az értékek egyértelmüen pozitív attitűdről tesznek tanúbizonyságot. A reklámokkal szemben felmutatott pozitív attitüd (4-es és 5-ös értékek) arányszámát az alábbi 1. ábra szemlélteti.

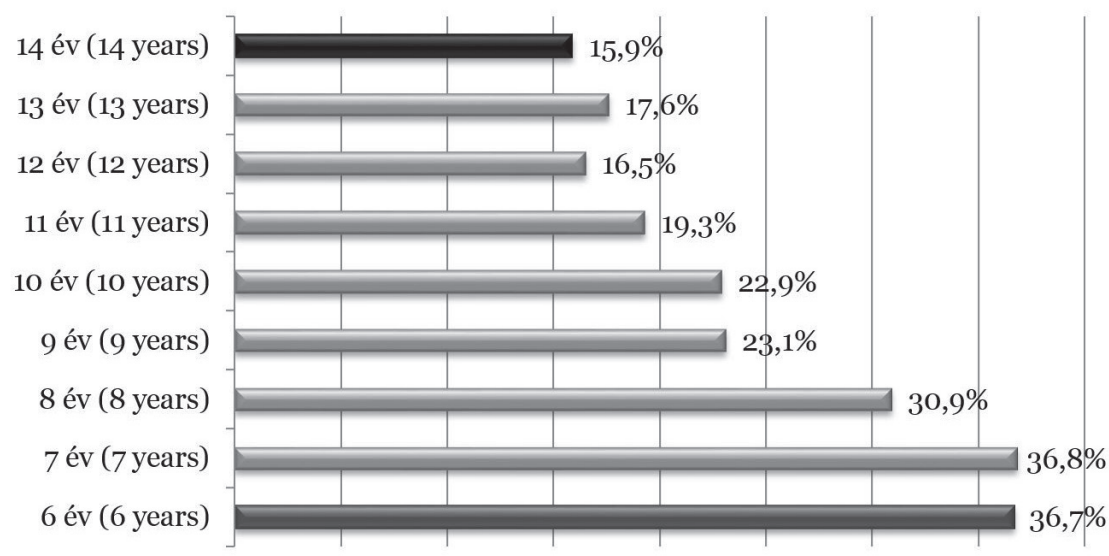

1. ÁBRA

FIG. 1

A reklámokkal szemben felmutatott pozitív attitüd aránya az életkor függvényében (Rate of Positive Attitude Presented to Ads Depending on Age)

Forrás (Source): Saját kutatás 2016 (Own construction)

A reklámokkal szemben felmutatott pozitív attitűd különösen fontos, mert a reklámban szereplő szlogen magán a reklámon eszközén keresztül éri el a befolyásolni kívánt gyermekeket, így koránt sem lényegtelen, hogy milyen a reklámeszköz megítélése. Az 1. ábra jól szemlélteti, hogy a legfiatalabb gyermekek a leginkább fogékonyak a reklámüzenetekre, ők mutatják fel leginkább a marketingesek álmát, a pozitív attitűdöt a reklámok kapcsán. Az életkoruk előrehaladtál a pozitív attitűd intenzitása jól kivehetően mérséklődik.

Általános tételként fogadható el, hogy a reklámokkal szemben felmutatott pozitív attitüd segíti a szlogen tudatban történő elmélyülését. A kutatás további szakaszának eredményeként összességében arra a következtetésre jutottam, hogy a megkérdezett korcsort tagjai (8-14 éves korosztály) igen magas arányban spontán fel tudják idézni a reklámokban hallott szlogenek alapján a márkaneveket. Ezt a legegyszerúbb módon a helyes válaszok arányával lehet mérhetővé tenni. Egy válasz helyesnek bizonyult, ha a gyermek a szlogen hallatán egyértelmüen, helyesen és pontosan a megfelelő márkanevet tudta megemlíteni. A gyermekek válaszát csak abban az esetben tekintettem helyesnek, ha az teljes egészében pontos volt a szlogen hallatán (a „valamilyen kóla”, a „valamilyen tejszelet” és „valamilyen Kinder” nem számított helyes megoldásnak). Az egyes szlogenek esetében mérhető a helyes és helytelen válaszok aránya, valamint a válasz elmaradása („nem tudom, nincs ötletem”) is. A kijelentés, miszerint a gyermekek igen magas arányban spontán fel tudják idézni a hallott szlogen alapján a termékek márkanevét - vagyis összességében magasnak tekinthető a helyes válaszok aránya - koránt sem ennyire egyszerü jelenség. A megállapítást több tényező is árnyalja.

A kutatás eredményeként megállapítást nyert az is, hogy a megkérdezett neme nem befolyásolja a helyes válaszok arányát. A gyermekek nemtől függetlenül adtak helyes avagy helytelen válaszokat. A helyes vagy helytelen válaszok arányát nem szerint vizsgálva alig 
néhány tizedes (sok esetben még annyi sem) eltéréseket tapasztalhattunk. A megkérdezett gyermekek neme és az adott válaszok helyes mivolta között számított Cramer-féle asszociációs együttható a különböző márkanevek esetében 0,02-tól o,06-ig ingadozott, amely mutató tökéletesen igazolja a fentebb leírtakat (az ismérvek gyakorlatilag függetlenek egymástól). Hasonló következtetésre juthatunk a lakóhely (község, falu, város, megyeszékhely, főváros) viszonylatában is. A lakóhely nem befolyásolja a helyes válaszok arányát. A Cramer-féle asszociációs együttható a megkérdezett gyermek lakóhelye és a válaszok helyességtartalma között független viszony állapítható meg $(\mathrm{C}=\mathrm{O}, \mathrm{O} 4$-tól o,o8-ig ingadozik terméktől függően).

$\mathrm{Az}$ életkornak viszont jelentős szerepe van a helyes válaszok arányának alakulásában. Az életkor előrehaladtával a helyes válaszok aránya rohamosan emelkedik. A legjelentősebb változás említve kiemelhetjük, hogy a CocaCola szlogenjének helyes beazonosítása a 6 éves korosztályban még „csupán” 50,4\% volt, mely arányszám a 13 éves korosztályhoz érkezve már 90,2\%-ra emelkedett. A különböző márkák esetében ez a változás a következőképpen alakult:

- Nesquik 40,5\%-ról 55,3\%-ra,

- Pöttyös 87,0\%-ról 99,2\%-ra,

- Cheetos 14,0\%-ról 38,8\%-ra,

- Sport szelet 16,3\%-ról 42,4\%-ra,

- Kinder tejszelet 20,2\%-ról 37,4\%-ra,

- Milka 14,5\%-ról 43,9\%-ra,

- Belvita JóReggelt 34,4\%-ról 74,8\%-ra,

- Chokito 11,5\%-ról 16,5\%-ra,

- Mizo 9,9\%-ról 24,2\%-ra,

- Boci 46,0\%-ról 59\%-ra emelkedett a helyes válaszok aránya.

Két termék esetében a fentebb leírt trendtől eltérően alakult a helyes válaszok aránya:

- A Kubu esetében 37,4\%-ról csökkenés figyelhető meg egészen a 30-32\%-os értékig. További vizsgálat hiányában ez a csökkenés arra enged következtetni, hogy a terméket a kisgyermekek preferálják leginkább (high involvement).
- A Kinder Pingui esetében elég hektikusak a helyes válaszok arányszámai. Legmagasabb a 6-7 éves korosztályban (48-50\%), amely az életkor előre haladtával csökken (36,6\%-ra), majd újra emelkedik (4248\%-os értékre).

Szükséges azt is megjegyezni, hogy (a már említett két kivételtől eltekintve) megfigyelhető az életkor előrehaladtával növekszik a helyes válaszok aránya, azonban ez a növekedés nem egyenesen arányosan, hanem sokkal inkább lépcsőzetesen következik be. Megfigyelhető, hogy a helyes válaszok arányának emelkedése a vizsgált korcsoportban jellegzetesen két lépcsőben következik be. A helyes válaszok arányában az első emelkedés a 8-9 éves korosztályban tapasztalható, míg a második jelentôsebb növekedés a 12-13 évesek korosztályában azonosítható. Fontos azt is megjegyezni, hogy a „kissé magára maradt” Chokito márkanév szlogen alapján történő visszaidézése nehézkes volt, a reklámköltések elmaradásával a szlogen ismertsége gyorsan csökkent, a feledés homályába veszett.

Az adatok mélyebb statisztikai vizsgálatára is lehetőség nyílott, melynek eszközéül a klaszter-analízist választottam (K-means Cluster). A szegmentációs ismérvek a fentebb részletezett okfejtésből következőek, a kognitív komponens mérésére szolgáló ismérveken (szlogenek ismertsége) túl az affektív, érzelmi komponens és a megkérdezett kora, mint fontos demográfiai tényező került bevonásra. A szegmentáció eredményét az alábbi 1. táblázat szemlélteti.

Az elemzés pontosságát és helyességét kiválóan bizonyítja, hogy minden változó esetében megbízható értékeket kaptam $(\mathrm{p}<\mathrm{0}, 001)$. Az F-ráta érétkei bizonyítják a változók helyességét és a szegmentációs ismérvek súlyát. A klaszterelemzés során 4 kialakított csoport (szegmentum) jelentett pontos megoldást, amely csoportok véleménye és tudásszintje is jól elkülöníthető. 
Az egyes márkanevek helyes felidézési aránya klaszterenként (Rate of Correct Answers of Different Brand Names According to Clusters)

TABLE 1

\begin{tabular}{|c|c|c|c|c|c|c|}
\hline $\begin{array}{c}\text { Állítás } \\
\text { (Statement) }\end{array}$ & $\begin{array}{c}1 . \\
\text { Szegmens } \\
(1 s t \\
\text { Segment) }\end{array}$ & $\begin{array}{c}2 . \\
\text { Szegmens } \\
\text { (2nd } \\
\text { Segment) }\end{array}$ & $\begin{array}{c}3 . \\
\text { Szegmens } \\
(3 r d \\
\text { Segment) }\end{array}$ & $\begin{array}{c}\cdot \\
\text { Szegmens } \\
(4 t h \\
\text { Segment) }\end{array}$ & $\begin{array}{c}\text { Átlagos } \\
\text { érték } \\
\text { (Average } \\
\text { Value) }\end{array}$ & $\begin{array}{c}\text { F-ráta } \\
\text { (F-rate) }\end{array}$ \\
\hline $\begin{array}{l}\text { Mennyire szereted a } \\
\text { reklámokat? } \\
\text { (How much do you like } \\
\text { ads?)* }\end{array}$ & 2,6 & 3,2 & 2,2 & 2,7 & 2,7 & 45,404 \\
\hline $\begin{array}{l}\text { Helyes válaszok aránya** - } \\
\text { Nesquik (\%) }\end{array}$ & 20,6 & 76,0 & 17,2 & 85,0 & 47,5 & 238,232 \\
\hline $\begin{array}{l}\text { Helyes válaszok aránya** - } \\
\text { Pöttyös Túrórudi (\%) }\end{array}$ & 87,0 & 98,4 & 97,4 & 99,2 & 95,2 & 24,926 \\
\hline $\begin{array}{l}\text { Helyes válaszok aránya** - } \\
\text { Cheetos (\%) }\end{array}$ & 6,1 & 34,4 & 11,3 & 45,1 & 22,9 & 92,659 \\
\hline $\begin{array}{l}\text { Helyes válaszok aránya** - } \\
\text { Sport szelet (\%) }\end{array}$ & 11,8 & 39,0 & 15,9 & 56,9 & 29,3 & 79,914 \\
\hline $\begin{array}{l}\text { Helyes válaszok aránya** - } \\
\text { Kinder tejszelet (\%) }\end{array}$ & 10,9 & 37,3 & 19,4 & 49,0 & 27,9 & 80,480 \\
\hline $\begin{array}{l}\text { Helyes válaszok aránya** - } \\
\text { Milka (\%) }\end{array}$ & 7,9 & 40,6 & 14,6 & 60,9 & 29,2 & 124,277 \\
\hline $\begin{array}{l}\text { Helyes válaszok aránya }{ }^{* *} \text { - } \\
\text { Coca-Cola (\%) }\end{array}$ & 41,5 & 84,4 & 76,4 & 92,5 & 72,3 & 100,607 \\
\hline $\begin{array}{l}\text { Helyes válaszok aránya }{ }^{* * *}- \\
\text { Belvita JóReggelt (\%) }\end{array}$ & 23,3 & 70,8 & 56,3 & 85,0 & 57,0 & 114,365 \\
\hline $\begin{array}{l}\text { Helyes válaszok aránya }{ }^{* *} \text { - } \\
\text { Chokito (\%) }\end{array}$ & 3,0 & 24,7 & 2,9 & 29,6 & 14,2 & 58,339 \\
\hline $\begin{array}{l}\text { Helyes válaszok aránya** - } \\
\text { Mizo (\%) }\end{array}$ & 2,1 & 21,8 & 5,5 & 33,2 & 14,6 & 49,599 \\
\hline $\begin{array}{l}\text { Helyes válaszok aránya** - } \\
\text { Kubu (\%) }\end{array}$ & 24,2 & 48,1 & 14,6 & 50,6 & 33,4 & 64,842 \\
\hline $\begin{array}{l}\text { Helyes válaszok aránya** - } \\
\text { Boci (\%) }\end{array}$ & 29,1 & 73,7 & 26,9 & 83,4 & 51,4 & 135,365 \\
\hline $\begin{array}{l}\text { Helyes válaszok aránya }{ }^{* * *} \text { - } \\
\text { Kinder Pingui (\%) }\end{array}$ & 35,5 & 52,9 & 36,9 & 51,4 & 43,7 & 17,629 \\
\hline $\begin{array}{l}\text { A megkérdezett jellemző } \\
\text { életkora (év) } \\
\text { (Age of the respondent) }\end{array}$ & 7,4 & 8,5 & 12,0 & 12,8 & 10,0 & 1448,037 \\
\hline $\begin{array}{l}\text { Szegmens részaránya a } \\
\text { sokaságon belül } \\
\text { (Proportion of segment) } \\
\text { (\%) }\end{array}$ & 27,5 & 25,7 & 25,8 & 21,1 & - & - \\
\hline
\end{tabular}

Forrás (Source): Saját kutatás, 2016 (Own construction, 2016)

Megjegyzés (Notes): *5 fokozatú Likert-skálán mérve, ahol 1 = egyáltalán nem, 5 = maximálisan ( 5 point Likert scale where $1=$ I don't like it absolutely, $5=$ I like it totally; ${ }^{* *}$ Rate of right answers) 
Jól látható, hogy a kialakított szegmentumok alapján két jellemző kategória figyelhető meg:

- Az első kategória képviselői azok a gyermekek, akik átlag alatti mértékben képesek a hallott szlogenek alapján a márkaneveket visszaidézni. Ezt a csoportot az 1. és 3. szegmentum tagjai alkotják. Megfigyelhető az életkorbeli jelentős eltérés is. Amíg az 1. szegmentumot jellegzetesen a legfiatalabbak alkotják (átlagos életkor a szegmentumon belül 7,4 év) a legcsekélyebb visszaidézési képességgel párosulva, addig a 3. szegmentum tagjait már a magasabb életkorral jellemezhetjük (12,0 életév). Jól látható az életkorból adódó tudástöbblet is, ami még jelen, emelkedett stádiumában is átlag alatti szintet ér el. A 1. szegmentum tagjait „távolról figyelőknek”, míg a 3. szegmentum tagjait „kimaradóknak” is nevezhetjük röviden.

- A második kategória képviselői azok a gyermekek lesznek, akik átlag feletti mértékben képesek a hallott szlogenek alapján a márkaneveket visszaidézni. Ezt a csoportot a 2. és a 4. szegmentum tagjai alkotják. Megfigyelhető itt is az életkorbeli jelentős eltérés is. Amíg a 2. szegmentumot jellegzetesen az ifjabbak alkotják (átlagos életkor a szegmentumon belül 8,5 év), addig a 4. szegmentum tagjait már a magasabb életkorral jellemezhetjük (12,8 életév). Jól látható az életkorból adódó tudáskülönbség itt is. Fontos megjegyezni, hogy az érdeklődő 2. szegmentum fiatalabb tagjai magasabb arányban tudtak helyes válaszokat adni, mint az idősebb, de a marketingre kevésbé fogékony 3. szegmentum tagjai. A 2. szegmentum tagjait „befolyásolhatóknak”, míg a 4. szegmentum tagjait „meggyőzötteknek” nevezem röviden.

Mindkét kategória esetében jól kirajzolódik a gyermekek életútja is. A legfiatalabb korban a „távolról figyelő” 1. szegmentum tagjaiból a későbbiekben lesznek a 3. szegmentum, a „kimaradók” tagjai, míg a „befolyásolható” 2. szegmentum tagjai az életkor emelkedésével a
4. szegmentum tagjai, vagyis a „meggyőzöttek” között találják magukat. Fontos megjegyezni, hogy a 4. szegmentum tagjai megdöbbentő pontossággal képesek a hallott szlogen alapján a márkanevet felidézni. Igazi reklámfaló szegmensról van szó, akiket már a marketing meszszemenőkig átitatott.

Igazán érdekes lenne annak vizsgálata, hogy milyen tényezők befolyásolják annak alakulását, hogy a gyermek mely szegmentumban (1-es vagy 2-es) kezdi „pályafutását” a fenti okfejtésben, mert ez kihat a jövőjére is. A marketing szempontjából a jövője pedig egyenértékű a későbbi befolyásolhatóságának mértékével. A 3. és 4. szegmentumokba való tartozás már egyfajta következmény, vagyis a korábbi gyökerek, a korábban már rögzült attitüdök kiteljesedésének következménye lesz. Nem elhanyagolható vélelmezhetően a család szerepe, az egyéb referenciaszemélyek, a látott magatartásminták, a televíziózással eltöltött idő mennyisége, a gyermek személyisége sem. Ezen hatások feltérképezése egy későbbi, kvalitatív kutatás témája lehet.

További vizsgálati eredményként a diszkriminancia analízis során a kialakított faktorok összevonása is megvalósult. A diszkriminancia analízis során az SPSS 2 funkciót (függvényt) állít fel, melyeket a korábban meghatározott faktorok összevonásával készíti el. Segítségével a kialakított szegmentumok (klaszterek) a korábban létrehozott faktorok dimenziójában grafikusan is ábrázolhatóvá válnak, látva és bemutatva annak helyességét. A szegmentumok ábrázolását, egymáshoz viszonyított térbeli elhelyezkedését a fenti funkciók alapján az alábbi 2. ábra szemlélteti.

A diszkriminancia analízis rámutatott a kor befolyásoló erejének fontosságára, ugyanis a megkérdezett kora 75\%-ban magyarázza az összvarianciát (1. funkció - függvény). Fenti ábrából látható, hogy a szegmentumok jól elkülöníthető csoportokat alkotnak. Az ábrán jól kivehetők a szegmentumok tudásbéli különbsége is. A felosztás pontosságát jól mutatja, hogy a megkérdezettek 95,0\%-át helyesen sikerült besorolni valamely csoportba. 


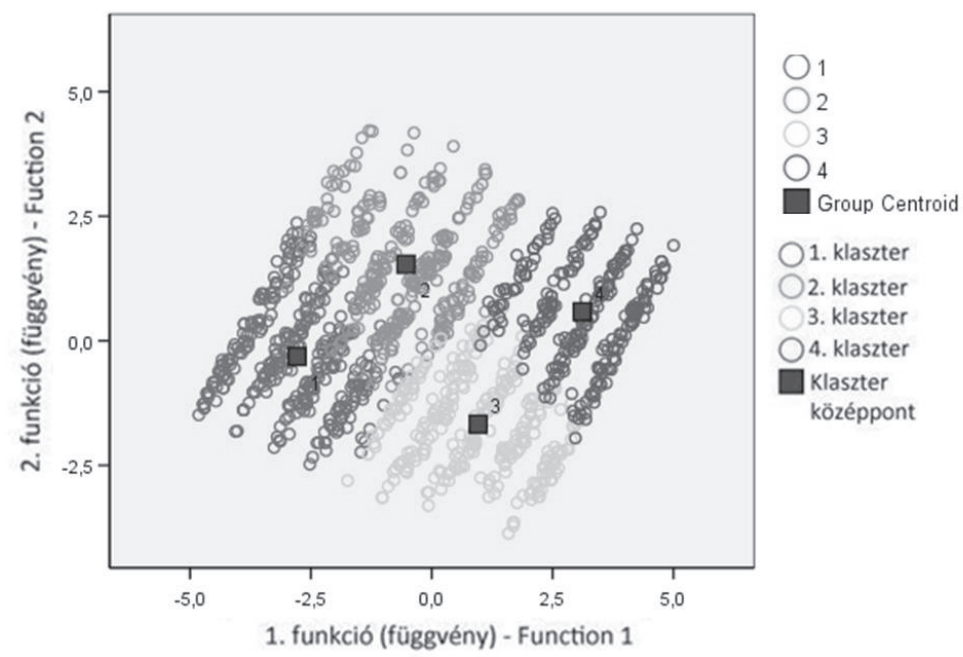

2. ÁBRA

A klaszter centroidok ábrázolása a diszkriminanciafüggvények tükrében

FIG. 2

Forrás (Source): Saját kutatás 2016 (Own construction) (Cluster Centroid of Different Segments)

\subsection{Változások az életkor előrehaladtával - kutatás 14 éves életkor felett - Changes with Age - Research Over 14 Years of Age}

Fenti eredmények tükrében felmerülhet egy jogos kérdés, mely a szlogenek felidézésének képességét kérheti számon a gyermekkor után. Vajon a fiatalkorúak, illetve a felnőttek milyen arányban képesek felidézni a gyermekkorúak számára említett szlogeneket? Vajon a megalkotott szegmentumok, illetve a besorolás a későbbiekben is helyesnek bizonyul vagy a szegmentumok határai az életkor előrehaladtával átjárhatóak? A kérdések megválaszolásához 610 fő fiatal- és felnőtt korú személyt kérdeztünk meg a korábbiakkal azonos kérdőív és a fentebb leírt módszertan segítségével. A kutatásban a megkérdezettek 44,8\%-a 20 éves életkor alatti (de 14 évestől idősebb), míg 55,2\%-a 20-30 éves életkor közötti volt. A megkérdezettek 49,3\%-a férfi, míg 50,7\%-a nő volt.

A fiatal- és felnőtt korúak szegmensénél már a vizsgálat kezdetekor megállapítást nyert egy fontos tény: A reklámokkal szemben felmutatott pozitív attitüd arányszáma, vagyis az 1. ábra 15,9\%-os záró értéke tovább csökkent a fiatal- és felnőtt korúak korosztályában (14 életév felett stagnál, majd változatlan értéket mutat) egészen 8,5\%-os értékre. Ha a gyermekkorban nem szerettettük meg a gyermekekkel a reklámokat, a szlogenünket, akkor azt a fiatalés felnőttkorban már nem fogjuk tudni elérni.

A kutatás eredményeképpen megállapítható volt, hogy a 14 évestől idősebb megkérdezettek esetében a helyes válaszok aránya már nem életkor függő, az jelentős befolyásoló erővel már nem bír. Az egyes szlogenekre adott helyes válaszok aránya és az életkor között számított Cramer-féle asszociációs együtthatók rendre nem- vagy rendkívül gyenge kapcsolatot mutatott. Ebból következően a további számításoknál, a 14 éves életkor felett már nem érdemes kiemelt figyelmet szentelni a megkérdezett életkorának, melyet az elvégzett klaszteranalízis F-rátájának értéke is igazolt $(\mathrm{F}=14,689)$.

Az egyes szlogenek esetében a helyes válaszok aránya a következően alakult a 14 évesnél idősebb megkérdezettek esetében (zárójelben feltüntetve a 13 éves életkorúak arányszáma):

- Coca-Cola 93,0\% (90,2\%),

- Nesquik 48,5\% (55,3\%),

- Pöttyös 99,2\% (99,2\%)

- Cheetos $44,8 \%(38,8 \%)$ 
- Sport szelet $46,6 \%(42,4 \%)$,

- Kinder tejszelet 25,6\% (37,4\%),

- Milka 44,8\% (43,9\%),

- Belvita JóReggelt 72,3\% (74,8\%),

- Mizo 23,6\% (24,2\%),

- Boci 58,4\% (59\%).

Két márka szlogenjének visszaidézési arányszáma a szokásostól eltérően alakult:

- A régi idők közismert márkája és annak szlogenje, a Chokito, átlagosan 31,8\%-os helyes visszaidézési arányt realizált. Ez jelentős emelkedésnek tűnhet a 13 éves életkorúak által felmutatott 16,5\%-os értékhez képest. Az eredményt azonban az életkor árnyalja: a 14 és 20 év közöttiek csupán 16,1\%-os helyességi arányt értek el, míg a 20 év felettiek 44,5\%-ot. Jól látható, hogy a 20 éves életkor felettiek még saját bőrükön tapasztalták a szlogen promóciós hatását, meglehetősen sokszor hallották azt, személyesen látták, kóstolták a terméket. A visszaidézési képesség az életkor emelkedésével sem tűnt el.

- A Kubu esetében az áltagos visszaidézési arányszám 45,6\%-os volt a fiatal- és felnőtt korúak szegmensében, míg a 13 éves életkorúak 32\%-os visszaidézési arányt értek el. A hatás itt is kettő tényező eredménye: a 14-20 év közöttiek átlag alatti visszaidézési arányt mutattak fel $(34,1 \%)$, míg a 20-30 év közöttiek jelentősen átlagon felüli, 54,9\%-os értéket. Vélelmezhető, hogy esetükben már nem a saját fogyasztás általi ismertség a domináns, hanem sokkal inkább annak köszönhető, hogy a terméket saját gyermeküknek vagy ismerősük gyermekének viszik ajándékba.
A gyermekkorúak esetében bemutatott szegmentációs eljárást (K-means cluster) a fiatal- és felnőtt korúak szegmensében is elvégeztem. A kapott eredmények szinte teljes egészében megegyeznek a korábbiakban bemutatottakkal (az életkor fontos szerepének kivételével), így annak részletes közléstől eltekintek. A szegmentumok ugyan olyan módon és arányban beazonosíthatók a fiatal- és felnőtt korúak szegmensében is, mint a gyermekkorúak esetében is beazonosíthatóak voltak. Kijelenthető, ha a gyermekkorú személy bekerült az 1. táblázatban részletesen leírt szegmentum valamelyikébe, akkor a besorolás az életkor előrehaladtával sem változik, az helytálló marad, a fogyasztó abban a szegmensben marad a fiatal- és felnőttkor periódusa alatt is. A fogyasztóknak a márkákkal és szlogenekkel öszszefüggő életútját az alábbi, 3. ábra segítségével illusztrálom.

A 3. ábra szemlélteti, hogy a fogyasztót számos hatás éri életútja során (mikro- és makrokörnyezeti hatások), mely hatások érvényesülési képességét meghatározza a fogyasztó személyisége is. A fogyasztó élet- és fogyasztói pályájának kezdetén besorolásra kerülhet a „távolról figyelők” (1. szegmentum) vagy a "befolyásolhatók" (2. szegmentum) valamelyikébe. Ezután a kezdeti besorolásnak megfelelően, az életkor előrehaladtával a fogyasztó vagy a „kimaradók” (3. szegmentum) vagy a „meggyőzöttek” (4. szegmentum) tagjai között találja magát. A marketing befolyásoló képessége a kezdeti irányvonalnak megfelelő erősséggel bír. A fiatal- és felnőtt korúakkal bővített kutatás alapján az is kijelenthető, hogy a fogyasztó érdekeltségi- és tudásszintje nem változik jelentősen a szlogenek világában. Emellett a két fő életút (1. és 2. szegmentum következményei) jól elválasztható egymástól, a határ nem átjárható. 


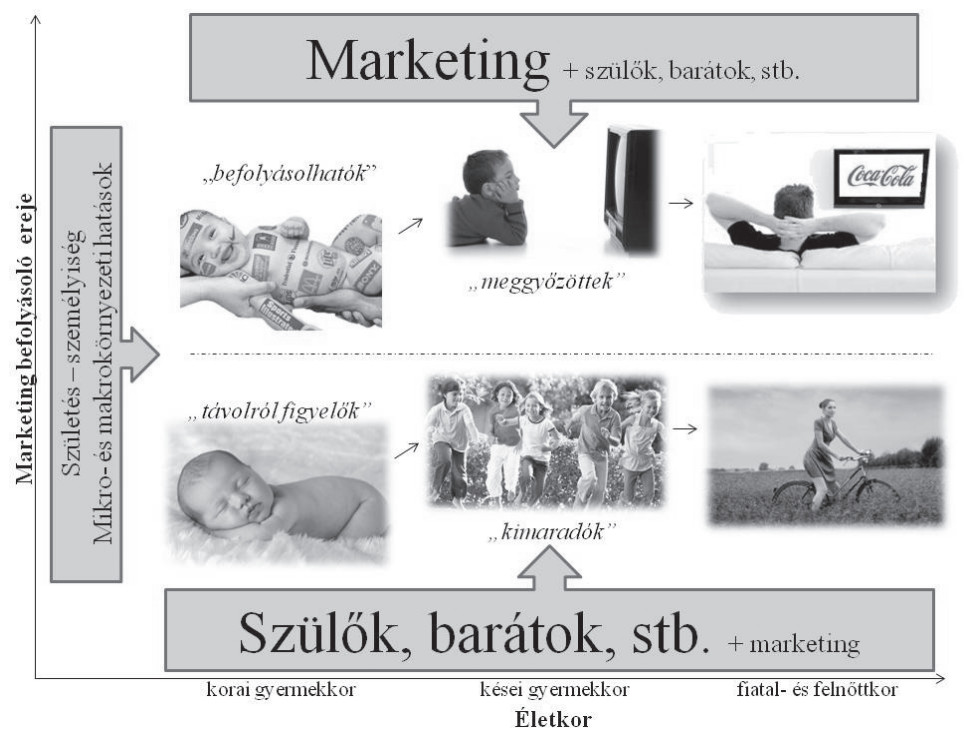

3. ÁBRA

A fogyasztó életútja a szlogenek világában

FIG. 3

\section{(The Lifecycle of Consumers in the World of Slogans)}

Forrás (Source): Saját kutatás és szerkesztés, 2016 (Own research and construction, 2016)

Megjegyzés (Notes): Marketing befolyásoló ereje = Influencing effect of marketing, Mikro- és makrokörnyezeti hatások - Micro and macro environmental factors, Szülők - Parents, Barátok - Friends, Befolyásolhatók - Influentables, Meggyőzöttek - Persuaded, Távolról figyelők - Consumers who are far away from marketing, Korai gyermekkor - Early childhood, Kései gyermekkor - Late childhood, Fiatal és felnőttkor - Youth and adults

\section{5. ÖSSZEFOGLALÁs - SUMMARY}

Összességében megállapítható és kijelenthető, hogy a food termékek piacán a gyermekkorban kialakított szlogen- és márkaismertség az életkor előrehaladtával stagnál, nem változik jelentősen. A siker titka nem a fiatal- és felnőtt korúak meggyőzésében rejlik. A befolyásolást már a gyermekkorban meg kell tenni. Nem elkezdeni szükséges a befolyásolást, hanem a gyermekkor végeztével befejezni. A gyermekkorú személyből már fogyasztót kell nevelni a fiatalkorba történő belépése előtt, ha sikereket akarunk elérni az élelmiszerek piacán. Joggal merülnek fel etikai aggályok a kijelentés kapcsán, vagyis mennyire etikus a gyermekek befolyásolása. A kérdés örök érvényü és vitatott. Egy dolog bizonyos, ha sikert szeretnénk elérni, akkor azt a gyermekkorúak szegmensében kell elkezdeni és realizálni, ott kell pozícionálni a szlogenünket, mert az egy életen át kitart és tartósnak bizonyul. Etikai aggályok vannak és léteznek, de a tény az tény marad: a siker titka a gyermekkorúak megnyerése. Kutatásom bizonyítja, hogy a fiatalkorúak védelme majd- hogynem felesleges a marketingingerekkel szemben. A 14. életév betöltésével már nem fiatalkorú személyről érdemes beszélni, hanem fiatal életkorú fogyasztóról, aki kiterjedt szlogen- és márkaismertséggel rendelkezik, aki a fogyasztói szocializációs folyamat útjának jelentős részét már megtette. A 14 éves fogyasztót már nem kell védeni, ôt már elérte és befolyásolta a marketing gépezete. Ha védeni szeretnénk a fogyasztót a marketing gépezetével szemben, akkor a kulcs a nem a fiatalkorúak védelmében, hanem a gyermekek védelmében keresendő. A felelősség megítélésem szerint a szülői felelősségen túl komoly állami feladat, egyik félre sem hárítható kizárólagosan. Jelen tanulmány kizárólagosan néhány élelmiszeripari szlogent von be a vizsgálat tárgykörébe, más szektor szlogenjeit nem vizsgálja. Feltételezhető, hogy más szektorok esetében is jelentős a szlogen visszaidézési képesség, olyan szektorokban is, melyek nem kifejezetten gyermekkorúaknak szánt termékeket népszerúsítenek. Ez azonban további kutatások hiányában egyértelmúen nem jelenthető ki. 


\section{IRODALOMJEGYZÉK - REFERENCES}

AGB Nielsen: A tévéképernyőt bámulva tölti a szabadidejét az átlag magyar. 2014. URL: http://www.mfor.hu/cikkek/ vallalatok/A_tevekepernyot_bamulva_ tolti_a_szabadidejet_az_atlag_magyar. html (Letöltés dátuma: 2015. máj. 23.)

Barta B. - Szúcs R. S.: Reklámozás, szlogen és szuperhősök - A gyermekek meggyőzésének eszközei. Táplálkozásmarketing. 2015. 2 (2) 47-58.

Coffey, T. J. - Siegel, D. L. - Livingston, G.: Marketing to the New Super Consumer: Mom \& Kid. Paramount Market Publishing Inc., Ithaca, 2006.

Comstock, G.: Television and the American child. Academic Press Inc., 1991.

Dersheid, L-E. - Kwon, Y-H. - Fang, S-R.: Preschoolers' Socialization as Consumers of Clothing and Recognition of Symbolism. Percept Mot Skill. 1996. 82 (3) $1171-1181$.

Dimo, O. - Colenciuc, I.: Advertising Slogans and Specificity of Their Translation. Intertext. 2010. 4 (13/14) 172-175.

Fischer, P. M. - Schwartz, M. P. Richards, J. W. Jr. - Goldstein, A. O.: Brand Logo Recognition by Children Aged 3 to 6 Years: Mickey Mouse and Old Joe the Camel. Journal of the American Medical Association. 1991. 266 (22) 31453148

Látos E.: Gyerekek, marketing, pszichológia és etika - összehangolható fogalmak? Budapesti Gazdasági Főiskola, Budapest, 2005. 18.

Linn, S.: Calories for Sale: Food Marketing to Children in the Twenty-First Century. The ANNALS of the American Academy of Political and Social Science. 2008. 615 (1) 133-155.
Macklin, M. C.: Preschooler's Learning of Brand Names from Visual Clues. Journal of Consumer Research. 1996. 23 (3) 251261.

McNeal, J.: Kids as Customers. NY, Lexington Books., 1992.

Piaget, J. - Inhelder, B.: La Psychologie de L'enfant. Paris, Presses Universitaires de France, 1966.

Piaget, J. - Inhelder, B.: Gyermeklélektan. Budapest, Osiris, 1999.

Rust, L.: Observations - Parents and Children Shopping Together: A New Approach to the Qualitative Analysis of Observational Data. Journal of Advertising Research. 1993. 33 (4) 65-70.

Simay A. E.: A gyerek, mint fogyasztó, EuroAstra Internet Magazin. 2009. URL: http://www.euroastra.info/node/22552 (Letöltés dátuma: 2016. szept. 16.)

Spurlock, M.: Super Size Me. Best Hollywood, Documentary, 2004.

Szúcs R. S.: A fiatalkorúak által fogyasztott néhány élelmiszeripari termék marketing és fogyasztóvédelmi szempontú vizsgálata. Doktori értkezés. Debreceni Egyetem, Ihrig Károly Gazdálkodásés Szervezéstudományok Doktori Iskola, 2011. URL: http://hdl.handle. net/2437/103324 (Letöltés dátuma: 2016. szept. 10.)

Újvári M.: Szlogenek: a jó szlogen, a vicces szlogen és a békebeli magyar szlogen. 2007. URL: http://www.sikermarketing. hu/szlogenek-jo-szlogen-vicces-szlogenes-bekebeli-magyar-szlogen (Letöltés dátuma: 2016. szept. 5.)

Vekerdy T.: Kérdezz! felelek... gyermekekről felnőtteknek. PARK Könyvkiadó Kft., Budapest, 2000. 